\author{
J. E. S. HAYWARD
}

\title{
EDUCATIONAL PRESSURE GROUPS AND THE INDOCTRINATION OF THE RADICAL IDEOLOGY OF SOLIDARISM,
}

I895-I9I4

On a previous occasion, I have argued that during the two decades preceding the First World War, the French Radical Party, under electoral pressure from the separate and then united Socialist parties of Jaurès and Guesde, began to look for a doctrine around which they could rally to defend their recently acquired hold on power against both the individualists to their right and the collectivists on their left. ${ }^{1}$ It was the six-month duration of Léon Bourgeois' purely Radical government of 1895-6 and his Lettres sur le Mouvement Social of 1895, republished in 1896 as a book and entitled Solidarité, that marked the beginning of the belle époque of Radical-socialism and of the Third Republic. It was argued that during the next two decades, Bourgeois' doctrine of Solidarism became for platform, and to a lesser extent, practical political purposes, the official social philosophy of the régime, probably reaching its apotheosis at the time of the Paris World Exhibition of 1900 . This pre-eminent position in the doctrinal firmament of France was not achieved without an intensive campaign through a variety of mainly educational pressure groups - to be anticipated in a lay "République des professeurs." It is the principal channels and people through which this indoctrination was propagated that will be our concern in the pages that follow. However, the activities of the "Universités Populaires", which were closely allied to the movements discussed here, have been passed over because they have formed the subject-matter of a separate study. ${ }^{2}$

\section{MACÉ AND THE MASONIC BACKGROUND}

No discussion of the origins of the social legislation of the Third Republic and the place of the idea of solidarity in French social

1 See my article "The official Social Philosophy of the French Third Republic: Léon Bourgeois and Solidarism", in: The International Review of Social History, 196r, VI, Part I, pp. 19-48.

2 "The Co-operative origins, rise and collapse of the "Universités Populaires", in Archives Internationales de Sociologie de la Coopération, Jan.-June I96I, IX, pp. 3-I7. 
and political philosophy in general and its dissemination by Léon Bourgeois and application by the Radicals in particular would be adequate without reference to the influence of Freemasonry as a movement and a set of ideals. The lodges became, during the Second Empire, the refuge of ex-Saint-Simonians such as Massol, the champion of a Proudhonian Morale Indépendante, who played a keyrôle in secularising French Freemasonry; Charles Fauvety, who had placed Le Représentant du Peuple at Proudhon's disposition in 1848 and was to expound under the Second Empire and Third Republic his pre-Solidarist mystique in his periodicals La Solidarité and La Religion Laïqu; and Dr. Ange Guépin who became a member of the Council of the "Grand Orient de France" and Prefect of Loire-Inférieure under the Second and Third Republics. It was in the Masonic lodges that such men worked out their new scientistic and humanitarian philosophy. During the Third Republic, the lodges developed into an immensely powerful propaganda and political machine, providing the indispensable instrument of organisation in an era in which French political parties were unorganised. Furthermore, it is probably no mere coincidence that "la maçonnerie devient, vers 1895 , radicale" the year in which Bourgois formed the first Radical Government of the Third Republic. ${ }^{1}$

At the beginning of the nineteenth century, Fourier had vaunted Freemasonry as "un des germes que la providence avait semés parmi nous pour nous offrir des voies de salut et d'acheminement à l'ordre combiné", whilst regretting their "gaucherie politique"; and SaintSimon, in company with many of his disciples, e.g. Leroux, Buchez, Massol, Guépin, Fauvety were Freemasons and had helped to transform its Revolutionary individualism into reformist Socialism. ${ }^{2}$ The most direct influence upon French Freemasonry and Léon Bourgeois had its source in the ex-Fourierist, Jean Macé, the founder-President

1 D. Halévy, La République des Comités, p. 30; cf. pp. 33-39 on Bourgeois' Government as marking a turning point in French politics. See also A. Dansette, Histoire Religieuse de la France Contemporaine, I95 I, II, pp. 69-7I.

2 Fourier, Quatre Mouvements, r808, p. 284; cf. 273-78; G. Weill, Histoire du Parti Républicain en France, 1900, p. 18; M. J. Headings, French Freemasonry under the Third Republic, p. 4I note, 57. On Dr. Guépin (1805-73) see R. Picard, "Un Saint-Simonien démocrate, le Dr. Ange Guépin" in Revue d'histoire économique et sociale, I925, XIII.

The place of the concept of solidarity in Masonic social philosophy is evident from the following quotation from a Projet d'un Manifeste Maçonnique, of 1869 , which appears in C. Bernardin's Précis Historique du Grand Orient de France, 1909. He refers to "un des points les plus importants de la morale, un de ses résultats les plus immédiats de ce grand principe, jusqu'ici assez mal compris et plus mal appliqué, qui constitue la solidarité entre tous les hommes. Cette solidarité n'est qu'une des conséquences de la fraternité" (p. q) and Freemasonry regarded as "absolument nécessaire l'étude approfondie et fraternelle des questions sociales; elle en recherchera la solution." (p. 13). 
of the "Ligue de l'Enseignement", whose principles and programme he explicitly stated were Masonic. Macé, a prolific vulgariser of laîc and anti-clerical doctrine, interpreted (twenty years before Lowe and half a century before the Popular University movement of Deherme), the coming of universal suffrage in $184^{8}$ as raising to primordial importance the need to organise "l'education du maître inculte". 1

During the Second Republic, as well as contributing articles on workers' associations to $L a$ Vraie République, Macé ran from November 1849 to June 18 so the Propagande Socialiste, an attempt to influence the politically backward Provinces by the dispatch of Republican and Socialist Parisian newspapers which provided valuable experience and contacts for the organisation of his subsequent propagandist campaigns in favour of the "Ligue de l'Enseignment", such as the petition in favour of the "Mouvement national du sou contre l'ignorance" in I 87I-72 - aimed at establishing compulsory free and lay education, achieved a decade later - which was supported by over one and a quarter million signatures and subscriptions. ${ }^{2}$

In I 866 Macé organised at Beblenheim, in Alsace, the "Ligue de l'Enseignment" and founded in 1868 - a by-product of the resurgence of the French co-operative movement in the 1860 's - the "Société de Crédit Mutuel agricole de Beblenheim", over whose destinies he presided. At this stage, the League stressed education for co-operation, launching an "Ecole Professionnelle de la Coopération".3 However, it already ambitiously posed in its first Bulletin, in r 868, as "La Ligue de la Paix à l'intérieur", which through popular education would deduce the practical implications of the "loi de solidarite"." The implications of this law were subsequently developed in an article on the League's philosophy. Conceived temporally, humanity created a common material and intellectual inheritance. The former was destroyed through consumption, and its scarcity rendered it a source of social inequality and conflict through individual appropriation. The latter, being unlimited and indestructible - growing not dimi-

1 J. Macé, La Ligue de l'Enseignement à Beblenheim, I862-70, I 890, p. 5; cf. 8, I8, 354; G. Compayré, Jean Macé et l'Instruction Obligatoire, 1903, pp. I6-19.

2 Compayré, loc. cit., pp. I8, 56, 85 .

3 Macé, loc. cit., p. 397; cf. M. Friedberg, Les conceptions méthodologiques et sociales de Charles Fourier. Leur influence, 1926, p. 144; J. Gaumont, Histoire générale de la Coopération en France, I, pp. 253, 519, 549, 589-9o. See Macé's article "De la Coopération appliquée à l'instruction" in: Almanach de la Coopération, 1868, pp. 64-66; a "Société générale coopérative de l'enseignment libre" being set up under the auspices of the League in 1868 (Almanach, 1869 , pp. 20-21.) On Macé's part in federating the Alsatian co-operatives, see Almanach de la Coopération, 1867, p. r 50.

- Macé, loc. cit., pp. 343-44. On the "Ligue de I'Enseignement" see F. Buisson's Nouveau Dictionnaire de Pédagogie et d'instruction primaire, I9I I, PP. ro39-4I. 
nishing with use - was a source of social equality and harmony, the individual being a victim of theft if he was denied "possession de tous ces trésors qui lui appartiennent, en sa qualité de membre de la famille humaine." In consequence, "la répartition plus équitable, entre tous les membres de la grande famille humaine, du trésor des connaissances, le patrimoine commun, est posée comme une oeuvre de justice sociale et de fraternité", constituting a "dette sacrée de la famille humaine envers tous ses membres, le droit qu'ont tous les hommes à la possession de ce qui appartient à tous."To implement this, Macé presented, in 1872 , a petition to the National Assembly demanding free and compulsory state education for all as a Solidarist right: "obligatoire dans le double intérêt de l'individu et de la société au nom de leur solidarité réciproque."1

The idea that had emerged under the Second Republic and germinated under the Second Empire, came to fruition under the Third Republic. In this process Macé played an important part by changing the emphasis within French Freemasonry from a quietist, mystical theosophy towards positivistic scientism and a practical preoccupation with popular education, friendly societies, co-operatives and legislative measures to reduce social conflict and social injustice within the nation, combined with efforts to reinvigorate the ideals of international brotherhood. In this connection, it is significant that the Committee of the "Cercle Parisien de la Ligue de l'Enseignement", set up in 1869 under Macé's Presidency, numbered Massol amongst its members, and in 1878 included Fauvety, the ex-Buchezian Corbon and the eminent scientist-politican Berthelot, with its Committee of Honorary Members presided over by Victor Hugo. ${ }^{2}$ The lodges of the "Grand Orient de France" in particular provided a forcing house, through their discussions of social and economic problems in which so many influential Radical and Socialist politicians participated. The author of French Freemasonry under the Third Republic points out that despite exaggerations of their influence by over-enthusiastic friends and unscrupulous enemies, "although there are some striking correlations between the projects of the French Masons and the laws passed by the French legislature, the Masons were not all powerful; they formed a strong pressure group that worked in co-operation with other Leftist organisations." Particularly important were the Radical and Socialist political parties, the "Ligue de l'Enseignement," the "Ligue des Droits de l'Homme" and "l'Union pour l'Action Morale". 3

1 Macé, pp. 369-74; Bulletin de la Ligue Française de l'Enseignement, 1904, p. 93.

2 A. Dessoye, J. Macé et la fondation de la Ligue de l'Enseignement, I883, p. 85 note, I 75 note; cf. Fauvety's review La Religion Laĩque, I878, p. 300.

3 M. J. Headings, op. cit., p. 8; cf. 104-21, I70 et seq., $203,208$. 
It was, in particular, in the 1890 's, when the increasing strength and influence of the Radical-Socialist party coincided with the influx of Radicals and Reformist Socialists of the type of Millerand, Fournière and Antonelli into the lodges, and Brothers Bourgeois and Mesureur created, in 1894, the "Action Committee for Republican Reforms" (which organised the first Congress of the Radical-Socialist party in I90r, with Bourgeois as one of the three Presidents), that French Freemasonry, most of whose lodges were affiliated to the Radical Party, became an influential vehicle for the dissemination and implementation of Solidarist ideas. Symptomatically, Léon Bourgeois' Cabinet of $1895-6$ included eight Masons amongst its ten members, and the principal reform it proposed, the progressive income tax, had been examined by all the "Grand Orient" lodges in I 891 and adopted in 1896.1 Whilst the Masonic idealists claimed to bring "au monde profane la grande conception morale solidariste", their political tactics and programme led them to campaign for "une solide majorité d'alliance radicale et socialiste qui pourra supprimer le budget des cultes et organiser définitivement la solidarité nationale", the "services publics de l'assistance et de la solidarité sociales" to be provided, following the separation of Church and State, out of the ecclesiastical funds. ${ }^{2}$ The "Grand Orient" had started a "Solidarity Fund" in I898, and in 1905 the "Brotherly Union of Employers" was formed, in the words of its motto, to "Practise solidarity by procuring work", whilst Masons belonging to the "Confédération Générale du Travail" formed a "Solidarité Syndicaliste". ${ }^{3}$ Such substantial straws bear testimony to the fact that Freemasonry was both influenced by and helped to spread and strengthen the influence of the idea of solidarity upon social and political organisation in France at the turn of the century.

\section{BOURGEOIS AND THE LIGUE DE L'ENSEIGNEMENT}

With the absorption of Alsace by the Germans in 1870 , Macé's League, which had by 1869 developed a thriving offshoot in the "Cercle Parisien de la Ligue de l'Enseignement", did not suffer by being severed from its geographical point of departure. On the contrary, thanks to Macé it spread rapidly throughout France until, in $188 \mathrm{I}$, the "Ligue Française de l'Enseignement" was formed to federate 1,298

1 Dansette, op. cit., II, pp. 247-49; Headings, pp. 71-75, I35, $183-84$. Bourgeois was a member of the "Bienfaisance Châlonnaise" lodge at Châlons-sur-Marne. (P. Nourrisson: Les Jacobins au Pouvoir, nouvelles études sur la Franc-Maçonnerie Contemporaine, 1904, p. 57).

2 Quoted by Nourrisson, loc. cit., p. 41, 122; cf. 66-67, 93, 109, 126-27, 256.

3 Headings, p. $175,199$. 
member "Sociétés républicaines d'instruction", with the "Cercle Parisien" acting as the Executive Committee. It received the official blessing of being "reconnu d'utilité publique" for its work in founding "bibliothèques populaires", "Sociétés Républicaines d'instruction" and in general promoting "popular" lay education.

Designated his successor by Macé, Bourgeois (who was President of the "Association Philotechnique"1 from 1893-96) was President of the League from $1895-98$, resigning when he became Minister of Education. The new President, Jacquin, proclaimed: "Associé avec Jean Macé dans la conception du but nouveau à donner à l'activité de la Ligue - autour de l'Ecole et après l'Ecole - Léon Bourgeois a jeté les bases de l'action, a su trouver les formules qui frappent, les images qui charment, les arguments qui convainquent"; and in his Presidential address to the 1899 Congress of the League, he said: "Ce sentiment de la solidarité dont notre ancien président, Léon Bourgeois, a donné la justification et la formule... il faut le faire pénétrer partout..." ${ }^{2}$ From his influential place in the League, Bourgeois, Honorary President from 1899, was able to encourage the diffusion of his doctrine of solidarity through its network of provincial bran-

1 The "Association Philotechnique" was founded in 1848 , when the pre-Solidarist upsurge of enthusiasm for adult and professional education led to a split in the too Conservative "Association Polytechnique" - itself the product of the Revolution of 1830 - which numbered Auguste Comte amongst its most active members. (A. Pressard, Histoire de l'Association Philotechnique, 1898, pp. 7-9.) Amongst the past presidents of the "Association Philotechnique" were such respected Republican dignitaries as Jules Simon (author of La Politique Radicale, I868, a pale version of the Radicalism of the Second Republic and heralding the Opportunism of the Third Republic), H. Carnot (sometime Saint-Simonian and controversially Minister of Education in 1848), Victor Hugo and Jules Ferry (who implemented the laïcisation of the French educational system in the I880's). (Ibid., p. 49.) Of Bourgeois' presidency from I893-96, Pressard affirmed: "ces trois années peuvent être comptés parmi les plus prospères de notre histoire." (Ibid., p. I 5 I. See also F. Buisson's Nouveau Dictionnaire de Pédagogie et d'instruction primaire, I9I I, Pp. I23-25.)

2 Bulletin de la Ligue, 1898, p. 373; Ib., 1900, p. 24. At this 1899 Congress, G. Cleiftie, in a report entitled De la Solidarité dans les oeuvres post-scolaires, proclaimed in words that echoed those of Bourgeois: "La solidarité ne remplace pas la fraternité; elle y ajoute la précision scientifique, la connaissance réfléchie des obligations sociales, le caractère rigoureux d'une dette... L'Ecole républicaine ne pouvait pas rester en dehors des conquêtes que poursuivent dans l'ordre économique et social, les idées de progrès et de solidarité... L'école toute entière n'aura plus qu'une âme - la solidarité." (Ib., I899, pp. 560-65.) For the detailed educational applications of the principle of solidarity envisaged by the Congress, see particularly the declaration "Qu'il y a intérêt de solidarité sociale à favoriser les relations entre les classes intellectuelles et les classes laborieuses", through the development of Popular Universities. (Ib., pp. 646-47.)

The Universités Populaires responded in kind, e.g. P. Pecquignat's lecture to the "Coopération des Idées", published in the periodical of the same name, May I899, pp. 54-55, on the need to teach "la morale de la solidarité". 
ches. More important than the outstanding personalities, historians such as Aulard and Seignobos, educationists such as Buisson and Petit, friendly society leaders such as Cavé and Mabilleau, poets such as Sully-Prudhomme and scientists such as Berthelot; more important perhaps even than the Deputies and Senators, lawyers and journalists, the publishers (Colin, Delagrave, Didot, Flammarion, Hachette, Plon), the League enjoyed the support of the active and enthusiastic avant-garde of the most influential profession in the laïc "République des Professeurs", the school teachers who were to popularise and disseminate the idea of solidarity so successfully in the Popular University and Social Education movements, as well as through their strictly scholastic activities. ${ }^{1}$

At the 1900 Congress of the League, a member of the General Council, Thalamas, categorically asserted: "La Ligue de l'Enseignement... consacre ses efforts au développement de la notion scientifiquement établie de la solidarité humaine. Le beau livre de son président d'honneur, M. Léon Bourgeois, Solidarité, peut être considéré comme le véritable manifeste de sa doctrine"; and so that there should be no uncertainty on this point the Congress resolved that in connection with all its activities, "il soit fait le plus souvent possible une allocution sur l'idée de solidarité et ses diverses applications." 2 In I 895, the year in which he published the articles that formed the first edition of his book Solidarité, Bourgeois had created and presided over a "Groupe d'initiative pour l'éducation sociale" with the aim of defining the term more precisely and propagating the means of impleplementing it through Popular Universities, producer, consumer and

1 G. Goyau, L'Ecole d'Aujourd'hui, I, 1899, pp. 163-67, 171, $215-220$. As the proSolidarist economist Charles Gide had observed: "Quand on inaugure une de nos nombreuses universités populaires, il est rare que l'orateur chargé du discours d'ouverture ne la présente pas comme une réalisation de l'idée de Solidarité." (Union pour l'Action Morale, 1.7.1900, p. 290.) Paul Crouzet in Etat actuel de l'Enseignement Populaire Social, a contribution to the I 900 International Congress on the Teaching of the Social Sciences, affirmed that "partout et par des moyens divers l'instituteur est un agent de concorde sociale, ne se contentant pas de prêcher la solidarité, mais solidarisant effectivement l'entourage de l'école." (I g00, p. 8 and passim.) The largest school tcachers' "Amicale" in Paris was significantly called "Solidarité". (Revue de la Solidarité Sociale, Aug. I905, p. 223.)

2 Bulletin de la Ligue, 1900, pp. 756, 905; cf. 505-10, 81 1, 976-78. E. Chaufour, Secretary of the "Union Démocratique pour l'Education Sociale," in his report to the same Congress, stressed the need to co-ordinate the multifarious social activities of the teachers: "il fallait une philosophie et une méthode. Elles sont en germe dans un petit livre dont le seul titre, Solidarité, me dispensera de vous citer l'auteur, trop connu de vous tous. Du principe nettement posé, les conséquences théoriques et pratiques vont sortir bientôt..." (Ib., p. 80I.) For Bourgeois' view of the Solidarist rôle of education, see Solidarité, I 896, 7th ed., I9I2, pp. 97-98, I30; Essai d'Une Philosophie de la Solidarité, rgoz pp. 82-84, 97; L'Education de la démocratie Française, 1897 , passim. 
credit co-operatives, friendly societies, etc., and in 1900 , the first Congress of the "Société pour l'Education Sociale" was held in Paris, being publicised in the Bulletin of the "Ligue de l'Enseignement". Under the Presidency of Léon Bourgeois, the Vice-Presidency of the Social Protestant politician Jules Siegfried and the President of the "Ligue de l'Enseignement", Jacquin, it included on its Committee the leading economist and consumer co-operator Charles Gide, the producer co-operator Henri Buisson, the Positivist trade unionist Keufer, the "Mutualist" leader of the friendly society movement and Director of the "Musée Social", Mabilleau, the Radical Professor of Education, Ferdinand Buisson, and the historian Charles Seignobos, as well as a galaxy of contributors, including Emile Durkheim, Charles Rist and Jules Payot. ${ }^{2}$ The latter was a particularly ardent supporter of Léon Bourgeois' ideas. In Aux Instituteurs et aux Institutrices (1897) Payot, an influential "Inspecteur d'Académie" and editor of the educational weekly Le Volume, discussing the key educational ideas to be taught, asserted: "Cette notion de solidarité est encore toute neuve dans le monde: elle est comme une Afrique nouvelle dont on n'a guère visité que le littoral ... La raison d'être de l'enseignement laïque, c'est le sentiment de cette solidarité humaine .. . Pénétrer la conscience des enfants et des adultes du sentiment de la solidarité humaine; éclairer leur idée de justice, c'est, nous ne craignons pas de le répéter, la tâche essentielle des éducateurs de tous ordres." 3

This apotheosis of the idea of solidarity generated tremendous enthusiasm, playing its part in that upsurge of associational and legislative activity which have left an enduring mark on French social institutions, orientating them in the direction of the "Welfare State". However, the impetus provided by the idea of solidarity soon began to slacken, despite efforts by the "Comité Girondin pour l'Education Sociale", whose Secretary, Emile Martin, recalled that throughout the nineteenth century "le solidarisme était latent et dès qu'il s'est affirmé

1 Bulletin de la Ligue, 1899, pp. 298-99; cf. Gide, Economie Sociale, 1903, pp. 28 r-82.

2 See Congrès International de l'Education Sociale, 26-30 Septembre I900, rgor; cf. C. Bouglé, Le Solidarisme, Ch. 6; H. Jagot, Le Devoir Social et les Universités Populaires, I902, pp. YI-I 5 .

On Durkheim's conception of solidarity, see my article: "Solidarist Syndicalism: Durkheim and Duguit", Part I, in: The Sociological Review, VIII, rg6o, pp. 17-36.

3 pp. 28o-84. In a comment upon the Essai d'Education Sociale d l'Ecole by J. Combes and L. Pastre, p. I, Jules Payot - who himself dedicated his Cours de Morale, 1904, to Léon Bourgeois, "L'Apôtre de la Solidarité" - wrote: "Combien vous avez raison de dédier votre travail à $M$. Léon Bourgeois, qui a fait sortir de l'Ecole le probleme de la solidarité et qui l'a posé au grand jour, créant par le développement de l'opinion publique sur ce point capital la Société d'Education sociale, qui sera, à brève échéance, un des grands organes de la pensée nationale." On Payot, see L. Capéran, L'Invasion laique, I935, pp. 228-3 I, 244-46. 
en sa doctrine homogène, on a été émerveillé de sa puissance." 1 The Second Congress in 1907 , held at Bordeaux, was a relative failure, the fiasco of the "Université Populaire" movement creating a contagious disillusionment with the efficacity of "social education". That Bourgeois' solidarist ideas had, however, established a secure foothold in the "Ligue" and in the official moral and social education expounded throughout France is unquestionable. Jacquin, as President of the League, declared at the Twenty-first Congress: "La Ligue n'a pas de dogme, ou plutôt elle n'a que deux principes qui s'imposent à nous comme la raison même de nos oeuvres: laïcité, solidarité. [Vifs applaudissements]". Meanwhile, the Bulletin rejoiced that through the "admirable éclosion d'institutions généreuses et fières se manifeste en ce moment la grande pensée de solidarité sociale qui sera bientôt le crédo de l'humanité." 2

\section{BUISSON AND THE APOTHEOSIS OF RADICAL IDEOLOGY}

Of at least equal importance to Jean Macé and Léon Bourgeois was Jacquin's successor as President of the "Ligue" in 1902, Ferdinand Buisson. If Macé pioneered the rise of education as the means to Radical social reform and Bourgeois had given it a credo, it was Buisson who was most influential in seeking to win for Solidarism the status of official ideology. He was admirably placed for this task because, in his person, he represented the convergence of the forces of neo-Protestant latitudinarian Christianity - he was the author of Le Christianisme libéral (1865) and Libre-pensée et le protestantisme libéral (1903) -, educational laïcism and socio-political Radicalism. After leaving France under the-Second Empire to succeed Charles Secrétan as Professor of Philosophy at the University of Neuchâtel in $1866^{3}$ he first became Inspector $(1871-78)$ and then Director

1 Alliance d'Hygiène Sociale, Aug. x905, pp. 96-99.

2 Bulletin de la Ligue, 1901, pp. 644, 912 ; cf. Ib., pp. 432, 442 sq., 730, 744, 778-79. At a lecture opening a nation-wide campaign on behalf of a solidarist, lay education, presided over by Léon Bourgeois, Jacquin said to him: "Nous n'avons fait que suivre votre exemple." (Ib., i 902, p. 6; cf. p. I8 I sq.)

${ }^{3}$ For Buisson's high opinion of the Swiss Social Protestant philosopher Secrétan, see Buisson's article in: Revue Pédagogique, 15.10.1886, p. 359. Buisson noted on the same page that a copy of Secrétan's La Question Sociale (1886) of which the article was a review, had been placed by order of the Ministry of Education in the libraries of every Ecole Normale! On Secrétan's admiration for Buisson, see L. Secrétan, Charles Secrétan, sa vie et son oeuvre, I912, pp. 414-I 5; cf. p. 374 et seq. On Buisson's Libetal Protestantism in Switzerland in the 1860's, see an autobiographical letter written in 1871 , published in G. Goyau's L'Ecole d'Aujourd'hui, I, 1899, pp. 264-66. On the influence of Quinet upon him, see Buisson's article in the Revue Bleue of 4.2.1888, pp. 136-37.

Pastor Gounelle, a leading Social Protestant, was an intimate friend of Buisson, whom 
(1879-96) of Primary Education at the instance of Jules Ferry during the years when the educational reforms that, it was hoped, would laïcise and republicanise France, were being planned, enacted and implemented. He played a major part - as the permanent civil servant who worked under Ministers of Education who came and went with Ferry, Bert, Goblet, Pécaut, Marion and Steeg in ensuring that public primary education in France became free ( $188 \mathrm{I}$ ), compulsory (I 882) and non-denominational (I886).

The periodical press played a vital rôle in the anti-clerical propaganda campaign and Buisson was at the forefront of the fray as editor of the influential Revue Pédagogique and the Manuel général de l'instruction primaire. ${ }^{1}$ In 1896 , the year in which Bourgeois' Solidarité was published, Buisson succeeded two leading Solidarists in key positions in the educational hierarchy. Firstly, Buisson replaced the disciple of Charles Renouvier, Henri Marion, as Professor of Education at the Sorbonne, devoting his inaugural lecture to the idea of solidarity. "C'est une idée qui a singulièrement grandi, Messieurs, depuis le jour où Marion l'introduisit en Sorbonne, et elle grandira encore. De tous les sentiments nouveaux qui ont germé en silence depuis une ou deux générations au fond de la conscience publique et dont l'éclosion un de ces jours étonnera ceux qui n'ont rien appris, n'ayant rien observé, le plus fort et le plus profond sans doute, c'est le sentiment du devoir social, disons mieux de la dette sociale qui pèse sur chacun de nous", which the Solidarism of Léon Bourgeois had formulated. ${ }^{2}$

Secondly, on Bourgeois' recommendation - Buisson, as Director of Primary Education, having been his close collaborator when he was Minister of Education from I 890-92 - Buisson succeeded him as President of the "Association Philotechnique" on the expiry of his three-year term, going out of his way to stress that "les changements de présidents se font sans changements de politique; c'est toujours la même politique, n'essayons pas de le cacher." 3 Thereafter, besides

he described as an assiduous and sympathetic reader of the Revue du Christianisme Social (Revue du Christianisme Social, 1932, pp. 190-92, obituary on Buisson). He was a member of Buisson's "Union des libres penseurs et des libres croyants", together with other Social Protestants such as Pastor Charles Wagner, Renouvierists like Séailles and co-operativists of the Ecole de Nìmes like Daudé-Bancel. (R. P. Dom Besse, Les Religions Laĩques, 1913, pp. 259-60; cf. p. 254.)

1 L. Capéran, L'Invasion laĩque, pp. 224-26.

2 Revue Internationale de l'Enseignement, 1896, pp. 497-98; cf. 501. On Buisson's career, see the article by E. Petit in: Bulletin de la Ligue de l'Enseignement, 1902, pp. 407-10; A. Pressard, op. cit., pp. 336-37; Marion, in: La Grande Encyclopédie, VIII, p. 390; Gounelle in: Revue du Christianisme Social, 1932, pp. 188-89.

3 Pressard, p. 183 ; cf. 148, I86, 346. On the exchange of letters between Bourgeois and Buisson, see the Revue Pédagogique, 1892, XXI, pp. 337-45, 389, 399. For an extended 
playing a prominent part in the Radical Party as Deputy of the Seine from I902-24, Buisson, as well as being active as a Mason, in the "Union pour l'Action Morale", the "Union des Libres Penseurs et de Libres Croyants pour la Culture Morale" (of which he became President in 1923)," in the "Ligue de l'Enseignement" (elected President in 1902), in the "Société pour l'Instruction Elémentaire" (presiding over it in 190I, following and preceding Bourgeois' Presidencies of i 900 and 1902), in the "Ligue des Droits de l'Homme" (over which he presided from I $914-26$ ), played a leading part in the foundation of the "Ligue Française d'Education Morale" in I91 2. ${ }^{2} \mathrm{He}$ crowned a half-

account of the collaboration between Buisson and Bourgeois to win the school-teachers over to Social Radicalism, see G. Goyau, L'Ecole d'Aujourd'hui, I, I899, pp. I6I-72. See especially note to p. 169 for Bourgeois' praise of Buisson, e.g. "C'est un fameux maître d'école, allez, même pour les ministres." (Quotation from Bulletin de la Ligue de l'Enseignement, I894, p. 287).

That the Solidarist evangel had penetrated a new generation is evident from the following resolution voted at the Second Congress of the "Jeunesses laiques" in I903. "La Morale laĩque doit être scientifique, sociale, humaine. Elle s'appuie sur la raison et sur l'expérience: $\mathrm{I}^{\circ}$ pour garantir et développer la liberté individuelle; $2^{\circ}$ pour assurer la justice sociale pat le solidarité nationale et internationale des individus et des peuples." (G. Weill: Histoire de l'idée laīque au XIXe siècle, p. 3 I9.)

Buisson was President of the "Association Nationale des Libres Penseurs de France" which provocatively held its first Congress at Rome in 1904. See L. Capéran, op. cit., p. 16I et seq., 3I6-2I. On June 7 th, 1907 was founded the "Union de libres penseurs et de libres croyants pour la culture morale" by a group which included Buisson, F. Drevfus, W. Monod and electing the Catholic heretic, ex-priest Hyacinthe Loyson, the Protestant economist and pacifist Passy and the rationalist disciple of Renouvier, Séailles as Honorary Presidents. Committee members included another disciple of Renouvier, B. Jacob, and the champion of the Universités Populaires and co-operativist disciple of Gide, DaudéBancel, whilst the Social Protestant Gounelle was a member of the permanent committee. (Bulletin Trimestrielle de l'Union de libres penseurs et de libres croyants, Jan.-March, 1908.)

2 The "Ligue Française d'Education Morale" absorbed the "Union pour l'Action Morale" - launched in I 892 by Paul Desjardins and particularly active during the controversy over the Dreyfus Affair -, which changed its title to "Union pour la Vérité" in I 906. Founded in June I91 2 by a group, of which Buisson and Charles Wagner were the most active members, the Ligue published an appeal, declaring: "il faut que les hommes de bonne volonté à quelque opinion qu'ils appartiennent, s'entendent en vue de l'action commune sur les points qui leur sont communs" with a view to achieving "dans chaque homme la dignité de la personne humaine et dans la société un idéal de justice et de solidarité fraternelle." (L'Union Morale, Organe de la Ligue Française d'Education Morale, Oct. I91 2, pp. 708.) It quickly rallied to its support a great many champions of the idea of solidarity: the philosophers Alfred Fouillée and Gabriel Séailles, the sociologists Bougle and Worms, the liberal economist Passy and the social economist Charles Gide, the educationists Jules Payot and Edouard Petit, the moralist Paul Desjardins, the social philanthropist Jules Siegfried, the reformist Socialist Fournière, the Social Protestants Elie Gounelle and Charles Wagner and the Radical Parliamentarians Léon Bourgeois and Ferdinand Buisson (Ib., p. 5o et. seq.) Amongst the associations which were members of the League were the "Association Philotechnique" and "La Culture Morale, Union des libres penseurs et des libres croyants" (Ib.. p. 58.) 
century of internationalist endeavour - going back to his articles for the ex-Saint-Simonian Charles Lemonnier's Etats-Unis d'Europe in 1869 - by receiving the Nobel Peace Prize in 1926, donating the proceeds to spreading the ideal of international solidarity. ${ }^{1}$ In a report to the 1905 Peace Congress, Buisson had stressed the need for an internationalist education based upon the notion of solidarity, whilst in 1918 , in a speech to the "Ligue des Driots de l'Homme", Buisson stressed the common aims and methods of the "Ligue" and Bourgeois" newly founded "Association française pour la Société des Nations"."

Buisson, who had in 1902 contributed to the symposium entitled Essai d'une Pbilosophie de la Solidarité the lecture on its educational implications, published in 1908 with a preface by Bourgeois, La Politique Radicale, which made a forceful attempt to set out the political principles and practice that followed from Léon Bourgeois' doctrine of Solidarism. Buisson argued that it was the idea of solidarity as formulated by Léon Bourgeois that gave Radicalism a distinctive social philosophy, that simultaneously assimilated it to and differentiated it from Liberalism and Socialism, combining the piecemeal gradualism of the former with the attack upon social injustice in all its forms: social, economic, educational, political of the latter. It was based upon the fact that "L'idée de liberté n'a rien perdu de sa force, mais une autre idée a surgi qui la complète et la rectifie, l'idée de solidarité." 3

Encouraged by Bourgeois' theory of social debt, the underprivileged sought social reforms to secure the effective enjoyment of their nominal rights. The Radicals, seeking to reinforce the solidarity of interests between all classes within a "mixed economy", refused to be driven to the extremes of either laisser faire individualism or statist collectivism. "Le parti radical ne s'enrôle ni sous la bannière de la propriété individuelle ni sous celle de la propriété collective, parce que

1 Bulletin de la Ligue de l'Enseignement, I902, p. 405. See Buisson's L'Avenir du Sentiment Religieux, 1923, pp. 27-31 on the foundation of the "Union pour la Culture Morale" in 1907 , its rôle until 1914 and its revival in 1923. See also H. Sée, Histoire de la Ligue des Droits de l'Homme, 1927, pp. I I 2, 2 1 5 ; cf. I53, 174. L'Union Morale, Organe de la Ligue Française de l'Education Morale, Oct. I9r2, pp. 5, 18-22, 1 10; G. Goyau, L'Idée de Patrie et l'Humanitarisme, pp. 63, 83-84; La Coopération Intellectuelle, 1929, p. 243; C. Bougle's Introduction to Un moraliste laique, Ferdinand Buisson. Pages Choisies, 1935.

2 Pages Choisies, pp. 123, r25, 136 et seq.

3 Buisson, La Morale Professionelle, p. 23, brochure consisting of a 1907 lecture at the "Ecole des Hautes Etudes Sociales", also published in the Revue du Mois, III, 10.3.1907, pp. 277-97. Buisson recognised, in La Politique Radicale, that Bourgeois' doctrine of Solidarism "fournit au radicalisme les données essentielles de sa politique sociale." (p. 2 10 et seq. for a vulgarisation of Solidarism. See also "La Solidarité à l'Ecole" in: Essai d'une Philosophie de la Solidarité, p. 189 et seq.) 
l'une peut couvrir les pires abus dans le passé, l'autre les pires chimères dans l'avenir ... Le débat vrai n'est pas plus entre la propriété individuelle et la propriété collective qu'entre la République de Platon et le phalanstère de Fourier. Il est entre ces deux conceptions de la démocratie: l'une osant garantir à tout être humain la liberté effective qui ne va pas sans un minimum de propriété, c'est à dire la sécurité, l'indépendance, la dignité humaine; l'autre effrayé des sacrifices qu'un tel changement couterait à la minorité privilégiée"; between political democracy with or without the social democracy that would alone emancipate from social injustice those hitherto denied their right to the benefits of social solidarity. ${ }^{1}$

To implement its policy of seeking a more equitable social order, free from the abuses of power by monopolistic capitalism, the Radical party envisaged action both by state intervention (including nationalisation) and through trade union and co-operative associations to "abolish the wage-system" in favour of a "property-owning democracy", within a framework of guaranteed social security and public assistance, of industrial legislation to protect the employed against the effects of accidents and unemployment, and a redistributed tax burden to ensure fiscal justice and provide the resources for a vast welfare and public works programme. Such were the reforms by which the Radicals such as Buisson sought to implement the ideology of Solidarity.

In the political context of the turn of the century, the inculcation of the Solidarist ideology cannot be separated from the anti-clerical campaign for the separation of Church and State that followed the Dreyfus Affair in both of which the omnipresent Buisson played such a leading part. He has been described as "l'éminence grise de Combes" and the "génie de la laïcité" whose life synthesised the history of turn of the century anti-clericalism. ${ }^{2}$ For him, politics and education had always been intimately interconnected, but in 1902 he shifted the emphasis from promoting the anti-cletical cause from within the many official and unofficial educational organisations with.which he was connected to overt political action in the Chamber of Deputies. The Radical party, reinvigorated by its first Congress of $190 \mathrm{r}$ and riding on a tide of anti-Right wing revulsion that followed the Dreyfus affair, was able to conduct a Kulturkampf counterattack upon its enemies and Buisson saw to it that this opportunity was exploited to the full in the educational if not in the economic sphere. Buisson astutely combined his old intellectual influence in various free-

1 La Politique Radicale, pp. 235-36; cf. pp. 218 et seq. For the influence of Leon Bourgeois' Solidarist theory of "social debt" on Radical policy, see e.g. Maurice Sarraut's policy declaration at the Toulouse Congress of 1904 (Ib., pp. $310-16$ ).

2 L. Capéran, op, cit., pp. $25-5$ I; cf. pp. 259-62, 27 I. 
thinking pressure groups and his politician's rôle as chairman of the Chamber of Deputies' Commission on the Separation between Church and State to strengthen the penetration of Radical ideology simultaneously from within and without the legislative process. However, his desire to go, like Jaurès, beyond an attack upon the Church to an attack - albeit attenuated - upon property was greeted with far less enthusiasm from the many middle-class supporters of the party and Buisson, for all his influence inside the dominant Radical party, remained a backbencher throughout his Parliamentary career in a political system where ministerial musical chairs was a feature of the political game. Instead of becoming the spearhead of social reform through state intervention, the efforts of Buisson and Bourgeois petered out in rhetorical flourishes and in the "safe" and inconsequential activities of the friendly society movement.

\section{THE FRIENDLY SOCIETY SIDETRACK}

Whilst it is invidious to single out an individual as personifying Solidarist activity in the schools, it is incontestable that, as the economist Charles Gide affirmed, it was a Vice-President of the "Ligue de l'Enseignement", "Edouard Petit, inspecteur général" (to which post he was appointed by Bourgeois in I 898), "l'homme qui a le plus fait pour le développement de ces cours et de toutes les oeuvres postscolaires" that flourished so luxuriantly at the turn of the century, in the form of Universités Populaires and Mutualités Scolaires, the latter beginning experimentally in I88I and spreading, until by 1906 the "Union nationale des Sociétés Scolaires et familiales de secours mutuels" grouped 720,000 members in 3,272 societies. ${ }^{1}$ Their initiator was J.-C. Cavé - who subsequently became Vice-President of the "Ligue de l'Enseignement" - receiving the official aid of Léon Bourgeois (as Minister of Education), and that of Buisson (as Director of Primary Education). They also received the unofficial support of the League and the "Union pour l'Action Morale" (whose Committee on the subject included Buisson, Macé and C. Guieyesse, future

1 C. Gide, Economie Sociale, p. 269, note; cf. article by Petit in: Emancipation, Feb. I904, p. 28 and his contribution to the Second "Congrès d'Education Sociale", 1907, under the title L'Education Sociale dans l'Enseignement, pp. 3-I3. See also L. Capéran, op. cit., pp. 222, 253; French Educational Ideals of 'To-day, 1919, Pp. 219-22, ed. F. Buisson and F. E. Farrington; E. Petit, La vie scolaire, 1907, p. 273 et seq. and A. Pressard, Histoire de l'Association Philotechnique, $x 898$, pp. $366-67$. The 1900 Congress on Primary Education had passed the following resolution: "Que les éducateurs de tous les pays aident à la propagation des sociétés de secours mutuels et de retraites entre enfants, afin d'entretenir dans les écoles de toutes les nations le sentiment de la solidarité." (Bulletin de la Ligue, 1900, p. 912.) 
Secretary of the Université Populaire movement), for the multiplication of what Bourgeois described as "ces sociétés de mutualité où s'acquiert l'éducation pratique de la solidarité", which inculcated the principles and practice of saving, social insurance and friendly societies and prepared the way for adult co-operation. ${ }^{1}$ Cave expressed the same sentiments when he proclaimed: "Par les bienfaits qu'elle procure à ses adhérents, par le lien qu'elle établit entre eux, la mutualité scolaire, oeuvre de solidarité humanitaire et de prévoyance sociale, est au premier rang parmi les meilleurs et les plus puissants instruments de sécurité, de concorde et de relèvement, que nous pourrions, avec notre Président (i.e. Bourgeois), préconiser au profit de la jeunesse de nos Ecoles."2

Friendly societies, which had been tolerated by the Second Empire, gathered force under the Third Republic, holding their first Congress in 1883 and receiving government subsidies from 1894 . Official interest took the form of the key Act of April Ist, I898, setting up a "Conseil Supérieur de la Mutualité". In praising "Les apôtres de la Mutualité, Mabilleau, Barberet, Cavé, Léon Bourgeois", the President of the Republic, Loubet, was officially recognising the contributions of these men to the mutual aid movement: Léopold Mabilleau (who had outlined the philosophical background to the idea of solidarity at the 1900 Congress on Social Education, being described by Bourgeois as "un solidariste pratiquant"), President of the "Fédération Nationale de la Mutualité Française" and Director of the "Musée Social"; Joseph Barberet in his official capacity as "Directeur de la Mutualité" in the Ministry of the Interior (a post which he took after being ousted from the trade union movement by Jules Guesde in 1879 , in which he had played a leading part in the 1870 's); Cavé, the champion of friendly societies for schoolchildren; finally, Léon Bourgeois, promoter and President of the Chamber of Deputies' "Commission de l'Assurance

1 Bulletin de la Ligue, I898, p. 226; cf. Ib. I891, pp. II pp. 74-84; 1900, pp. 509-10; Gide, Economie Sociale, Pp. 278-80; Bulletin de L'Union pour l'Action Morale, I 5.1 2.1894, pp. 64-65; L. Mabilleau, La Mutualité Française, 1904, pp. I03-1 2.

2 Bulletin de la Ligue, 1898, pp. 209-I0. It was with Buisson's help - then Director of State Primary Education - that Cave launched and popularised the friendly society in the schools. See the article by Buisson in: Le Siècle, 4.2.1899, quoted at length by M. Turmann in: L'Education Populaire, 2nd ed., 1904, pp. 22-27, a well-documented study of the adult education movement, written from the Social Catholic viewpoint.

On the contrast between the individualist and solidarist conceptions of the friendly society, see F. Alengry's criticism of the Bastiat-inspired book on La Mutualite by F. Lépine which described the "multualité scolaire", which went beyond mere personal saving and insurance, as a manifestation of "collective theft", "legal beggary" and the transition to "ultra-socialism". (See Alengry's article in: Revue Pédagogique, 1904, I, pp. $257-63)$. 
et de la Prévoyance sociale" and president of innumerable mutualist assemblies and of a friendly society. Bourgeois championed voluntary and private efforts at social insurance on the one hand and state intervention to sustain, subsidise and supervise them on the other, as well as preventing the social evils and minimising the social risks which mutual aid merely remedied by a comprehensive public health campaign." At the "Grande Fête des Oeuvres de Prévoyance et de Mutualité" of the "Association Générale du Commerce et de l'Industrie des Tissus et des Matières Textiles" in 1905, its President, Parison, invoking "un des maîtres éminents de la philosophie mutualiste, M. Léon Bourgeois", proclaimed before an audience which included some of the most eminent official personalities from the President of the Republic down: "La Solidarité, voilà le Crédo de notre époque." 2 However, as the Mutualist leader Mabilleau himself recognised, for the full development of the sense of solidarity it was necessary to pass from reparative mutual aid to constructive co-operation in production, consumption and credit, and the "Ligue de l'Enseignement" proclaimed the need to develop co-operatives in the schools to make of the future citizen, from childhood, "un solidariste éclairé et conscient de son rôle." 3

Revue de la Solidarité Sociale, Dec. 1905, p. 284; Solidarité, p. 78 ; cf. Politique de Prévoyance, I, pp. 35-40, 130-199. Bourgeois suggested (Ib., II, pp. 174-77), functional specialisation between the services provided by voluntary associations and the state, the former concentrating on health and the latter on pensions. The editor of the Revue de la Solidatite Sociale, Lantelme, whilst praising friendly societies for their "éducation solidariste de la classe moyenne, si nombreuse en France et qui demeure si volontiers figée dans la paix opportuniste", regarded it, like Bourgeois (to whom he explicitly referred) as requiring supplementation by state intervention: "Le progrès naturel de l'idée de solidarité sociale impose à la conscience nationale la nécessité de l'établissement des retraites ouvrières obligatoires." (Revue de la Solidarite Sociale, May 1905, p. 161; cf. 162-63; Ib., Aug. 1905, article on "Solidarité et Mutualisme", pp. 235-36.)

2 The official support for the friendly society movement is evidenced by the testimony of Cruchon, Préfet of l'Ardèche, who indoctrinated the schoolteachers of each canton in his departement, proclaiming that "La mutualité est la forme supérieure de la préroyance et de la solidarité"; one of the "institutions sociales basées sur la connaissance plus exacte des lois de la solidarité sociale et des moyens d'y conformer les rapports volontaires des citoyens entre eux... Avec de tels citoyens, le XXe siècle ne sera pas le siècle du socialisme; il sera le siècle de l'association, de la coopération, de la mutualité, de la fraternelle solidarité..." (Bulletin de la Ligue, 1899 , pp. 69-7x). It was such a politically-motivated campaign that led Charles Gide ironically to rematk that by comparison with syndicalism "La mutualité cause moins de soucis aux gouvernants: au contraire, elle lui offre l'occasion dans de nombreux congrès et banquets de célébrer les bienfaits de la solidarité." (Les Sociétés Coopératives de Consommation, p.v. Preface to znd ed. xg1o.)

3 Mabilleau affirmed: "La mutualité ne vise que les accidents, les revers, les maux de la vie. La pratique de la solidarité ne doit pas s'en tenir là; elle doit s'étendre à l'exercise même de la vie, en ses fonctions essentielles et normales. En ce sens, elle prend le nom de coopération..." (Quoted in Bulletin de la Ligue, I901, p. 420.) Cf. L. Mabilleau, La Mutua- 
By 1914, the Radicals had lost most of their working class clientèle to the Socialists and following the Bolshevik Revolution of I9I7, the conflict on the left was between Socialists and Communists, not between Socialists and Radicals. Simultaneously, the Radicals developed their ties first with small and then big business and their grandiose ideology increasingly dissipated itself in hollow phraseology, the notion of solidarity ceasing to symbolise the avant-garde aspirations of the Parliamentary left. The party of Léon Bourgeois and Ferdinand Buisson preoccupied with avoiding enemies on the left became the party of a justemilieu bourgeoisie, increasingly concerned to avoid enemies on the right. A narrow, anti-statist neoliberalism replaced an interventionist social radicalism. Radicals were to occupy power without exercising it, the erstwhile champions of social reform degenerating into a congeries of predominantly reactionary groups who enjoyed closer ties with the C.N.P.F. than with the C.G.T. except on exceptional occasions like the Front Populaire of 1936. In domestic policy, even in matters such as traditional anticlericalism, to which most Radicals remained faithful, they were increasingly forced onto the defensive. Previously powerful pressure groups, like the "Ligue française de l'Enseignement", have not been successful in defending the laïc principles established in the face of bitter campaigns during the Third Republic on apparently firm foundations.

In the 1950's - and particularly since the establishment of the retrograde Fifth Republic - Radicalism increasingly diluted its ideology. In terms of the line up in the first decade of the Third Republic, the Radicals were outdoing Gambetta in Opportunism. The remarkable attempt in the mid-1950's by Pierre Mendès-France to revive the intransigent Radical tradition of Louis Blanc failed and the Radical party has resumed a decline in which it may loose all raison d'être. The "radicalisation" of the S.F.I.O., under the influence of social, political and personal factors has led to the Radicals being eroded by the Independents and Gaullists on the Right and the Socialists and the P.S.U. on the Left. However, if it has lost all else, French Radicalism has probably not lost its genius for survival.

lité Française, 1904, pp. 18, 25-33, 40, 54-55, 67, 82, 153, 183, which ends by describing the friendly society as an "oeuvre de liberté généreuse et de démocratique solidarité" (p. 200). See also, Mabilleau's brochure La Coopération, ses bienfaits et ses limites, 1895 .

The 190 I Congress of the League passed the following resolution: "Considerant que les oeuvres post-scolaires sont surtout des oeuvres d'éducation et de solidarité, le Congrès émet le voeu que les coopératives soient établies par leurs soins, qui permettront d'appliquer les principes de la solidarité, de trouver, dans l'emploi des bonis, les ressources nécessaires au développement du lendemain de l'école." (Bulletin de la Ligue, igor, p. 428.) 